\title{
Farewell, king coal!
}

\author{
Anthony Seaton
}

\section{Correspondence to \\ Professor Anthony Seaton, University of Aberdeen Medical \\ School, Aberdeen, UK \\ a.seaton@abdn.ac.uk}

AS was director of the $10 \mathrm{M}$ from 1978-90.

Received 15 January 2016 Accepted 17 January 2016

Published Online First

8 February 2016
CrossMark

To cite: Seaton A. Thorax 2016;71:364-366.

\section{ABSTRACT}

Coal mining provided the power for the industrial development of the West, at great cost to the health of the workforce and, from industrial pollution, of the population. Medical appreciation of the diseases of miners was slow to develop and has been marked by controversy relating to the roles of coal and quartz and the causation of emphysema. Research by the MRC and the British coal industry resolved these issues as the industry itself declined. However, from the research has come an understanding of the influence of inhalation of different inhaled pollutants on human health that has been applied to predicting and preventing possible hazards of developing nanotechnologies.

For God's sake, let us sit upon the ground

And tell sad stories of the death of kings...

Last year, 2015, was marked by the closing of the last deep coal mine in Britain, Kellingley Colliery. The history of coal exploitation has been central to the history of Britain, both in its rise to world economic prominence and in its industrial decline. It illustrates remarkably well the consequences, good and bad, of disruptive technologies and thus holds lesson for all of us, now in a further period of such disruption.

The earliest records of the use of coal in Britain come from Roman times but until the 18th century it was only used locally for domestic heating and, more generally, in lime kilns and metal working. The first deep mines were dug in Northumbria and around the Firth of Forth in the late 18th century, areas from which the mineral has been extracted ever since. However, wood, charcoal and water remained the major sources of heat and energy, and commercial use of coal on a grand scale started only after James Watt's improvements on Newcomen's engine, patented in 1776. Coincidentally, that same year Adam Smith published 'The Wealth of Nations', leading to an overoptimistic understanding of the use of capital in industrialisation by the West. It is not unreasonable to regard this date as that from which coal became the dominant influence on the world's economy, spread by British steamships to the furthest corners of the Empire. Coal became king and Britain had endless supplies.

Of course the extraction of coal, especially from the deep seams, is a dangerous and dirty process, something that seemed to concern most of the owners rather less than it should have. In the 1840s some 250000 people, a quarter of them women and children, were employed in coal mining, many having transferred of necessity from work on the land. The dreadful conditions and the employment of women and very young children in this trade passed unremarked by legislators until a disaster in which 26 girls and boys drowned in a mine in 1838. Queen Victoria ordered an enquiry led by the 7th Earl of Shaftesbury, Anthony Astley Cooper. The consequent report of the Royal Commission on employment of children in the mines was published in 1842 . The illustrated verbatim stories of these women and children make distressing reading; they were in servitude to their masters-truly slaves. ${ }^{1}$ The report affected Parliament so much that regulation, the first Mines Act prohibiting employment of women and children under 10 years old, was introduced the same year-a small step in the right direction. In his speech to Parliament, Shaftesbury said: "Surely it is evident that to remove, or even to mitigate, these sad evils will require the vigorous and immediate interposition of the legislature. That interposition is demanded by public reason, by public virtue, by the public honour, by the public character, and, I rejoice to add, by the public sympathy: for never, I believe, since the disclosure of the horrors of the African slave trade has there existed so universal a feeling on any one subject in this country, as that which now pervades the length and breadth of the land in abhorrence and disgust of this monstrous oppression".

By 1920, 1.2 million men were employed in coal mining in UK, almost $20 \%$ of the adult male population. Thereafter the industry came under economic pressure and steadily reduced its workforce while increasing its productivity; it was always a leader in technological innovation. But this came at a price. The history of coal mining has been punctuated by frequent major disasters from explosion, flood, gas and roof falls, almost daily individual accidental deaths and even disasters from events external to the mine such as the deaths of 116 children and 28 adults from a spoil-tip collapse at Aberfan in 1966. Alongside this has been the toll of death and injury from mining diseases. A particular disease of miners characterised by black lungs, later called coal worker's pneumoconiosis (cwp), was illustrated by Laënnec in the early 19th century but through much of the 19th and early 20th century the fact that miners died from lung disease, recognised by occasional reports from Scotland, was partly concealed by the universal prevalence of TB among working people living in crowded and insanitary conditions; in 1920 the average male life expectancy at birth was 57 years. However, the introduction of radiography and rise of pathology in medical practice brought the attention of doctors to particular problems of chest disease in mining areas, especially South Wales.

At first doctors were sceptical, the scientist JS Haldane having pronounced that coal dust, in 
contrast to quartz (crystalline silicon dioxide), was harmless to the lungs. ${ }^{2}$ For a long time it was believed that when lung disease occurred in miners it was caused by quartz rather than coal. However, it was first shown that radiological changes occurred in men exposed to coal without quartz; ${ }^{34}$ then pathologists in South Wales, notably Gough and Cummins, drew attention to two important observations: first that the microscopic features in men exposed to coal differed from those in men exposed to quartz ${ }^{5}$ and, second, that the lesions in coal miners were associated with emphysema. ${ }^{6}$ As World War II drew to a close, the huge burden of respiratory disease among coal miners became apparent, and investigation by the Medical Research Council (MRC) in Wales began to define the size of the problem and its association with coal dust exposure. $^{2}$ Compensation for respiratory disablement was extended from miners exposed to quartz to all coal miners and the MRC set up its pneumoconiosis unit in Penarth under Fletcher, producing the first evidence of an exposure-response relationship between dust exposure and certification of disablement. ${ }^{2}$ But it also became apparent that pneumoconiosis and disablement did not necessarily coincide.

At this point, in 1946, the Attlee government nationalised the UK coal industry and the new National Coal Board (NCB) was confronted with the problem of dealing with an apparent epidemic of lung disease in miners-both how best to manage the several thousand men who were being compensated for lung disease each year, and how to prevent further damage to the health of as-yet-unaffected miners. The MRC under Fletcher and then Gilson had been active in establishing epidemiological methods for measuring symptoms, lung function and, later, taking standardised chest radiograph readings. ${ }^{2}$ An ex-MRC doctor, John Rogan, was appointed the chief medical officer of the NCB and had the good fortune of having two very sympathetic senior colleagues, the Chairman Lord Robens and the Director of Research, the polymath Dr Jacob Bronowski. In a classic example of research conception, Rogan posed two questions: how much and what types of dust cause pneumoconiosis, and what levels of dust need to be maintained to prevent men becoming disabled from the air they breathe? This implicitly acknowledged that disablement might not necessarily have been directly related to cwp; thus in 1953 was born the NCB's Pneumoconiosis Field Research, supported by both management and trade unions. Twenty different collieries, representing the geography and range of geological conditions of the UK coal fields, were selected and the miners, ultimately some 50000 , became the subjects of the research. Estimates of dust exposure, based on detailed occupational histories and measurements by specially designed dust samplers (that selected and allowed weighing of the fine particles expected to reach the alveoli ${ }^{7}$ ), were made for each subject and updated 4-yearly. Symptoms, lung function and chest radiological category were measured at each visit by a mobile unit. In 1969 the team of doctors, statisticians, physiologists, environmental scientists and technicians were established by the NCB as an independent research charity, the Institute of Occupational Medicine (IOM), in Edinburgh. By 1971 the first results of the analyses were published, showing relationships between the dust exposures of the miners and their risks of developing pneumoconiosis; these were used by governments and industry to set dust standards in the UK and USA to reduce risks of cwp. ${ }^{8}$

Of equal importance to reducing risks of cwp was the prevention of disability. By the 1970s the views of Haldane had been shown to be wrong; coal did indeed harm the lung by causing cwp which could be disabling. But did it also cause what had become the predominant lung disease in industrialised countries, COPD, then called chronic bronchitis and emphysema? In spite of the fact that Osler in the 1895 edition of his textbook had taught that coal dust was a cause of this, ${ }^{8}$ that Cummins in the 1930s had shown the breakdown of the lung's elastic tissue in miners and thus provided a plausible explanation for the development of emphysema ${ }^{6}$ and that the MRC had published a relationship between dust exposure and disablement, ${ }^{2}$ many doctors and scientists opposed the view that coal caused COPD. Part of the reason for this was that by then smoking had become almost universal in men and this was regarded as a more likely cause in miners. Nevertheless, further epidemiological and pathological studies by the IOM, allowing for smoking effects, showed clear relationships between exposure to coal dust of different types and risks of symptoms of bronchitis, impaired lung function and presence of emphysema pathologically, ${ }^{9-13}$ while also showing experimentally a mechanism supporting Cummins's early views on elastin breakdown. ${ }^{14} 15$ In 1993 COPD was accepted in the UK as a prescribed disease for compensation in coal miners.

It is an irony of history that this research outcome coincided with the terminal decline of the UK coal industry, but from its ashes has arisen a phoenix. The origins of the decline lay in the increasing cost of coal production in an increasingly globalised economy, hence the reductions in manpower and pit closures overseen by Robens and his successors. Cheap coal from overseas replaced indigenous coal and the numbers of men at risk of accidents and disease fell. What remained of the coal industry, then British Coal, was privatised in 1994 and has now practically disappeared. But the IOM, founded to answer coal questions, had greatly expanded its national and international research interests in preventive environmental medicine, was able to survive threatened closure in 1988 and still thrives as an independent research charity. Part of the reason for this curiously also relates to coal.

The progressive industrialisation of Britain from the time of the restoration of the Stuart monarchs ${ }^{16}$ had been characterised by urban pollution, smog. The widespread availability of coal for domestic and factory use exacerbated this winter problem and in the 1950s such smogs were shown to be associated with a great excess of deaths among older people, adding to the toll recognised in the workforce. Even later, as urban smoke was controlled by regulation of coal burning, it was shown that excess deaths still occurred in pollution episodes and that many of these were surprisingly from heart disease. Research into ambient pollution had become an important focus of research, and it led to the hypothesis that the generation by combustion of huge numbers of very small particles, nanoparticles, with very low mass but a very high surface area is capable of initiating biological reactions in the lungs leading to effects on distant organs. ${ }^{17}$ This hypothesis was published as physicists and chemists were becoming excited by the possibilities of nanotechnology, while others were debating the dangers implicit in unregulated disruptive science leading to out-of-control nanobots. Input of rational thinking to this debate by the Royal Academy of Engineering and the Royal Society allowed development of the technologies to continue, and led to the new science of nanotoxicology investigating the possible downsides. ${ }^{18} 19$ This is the first example of hazards of a new technology being investigated before anyone involved had been harmed by it; ${ }^{20}$ already some preventive regulations with respect to nanofibers have been introduced.

The final chapter of the coal story is now being written. It relates back to the first chapter and the Industrial and Agricultural Revolutions, which enabled the planet to provide a rapidly growing population with its energy and food needs. The combustion of fuels derived from the Carboniferous period has 
led to a steady increase in carbon dioxide in the atmosphere while levels of methane have risen with the increase in agriculture. The consequences are now becoming obvious even to scientifically illiterate sceptics, as sea levels rise, deserts expand and floods and storms increase. ${ }^{21}$ The era of coal and other fossil fuels is over, either from rational action by governments or ultimately by default as bacteria do battle with the survivors of Homo sapiens. Perhaps an observer from space might wonder whether sapiens is an apt descriptor of 21 st century mankind.

For within the hollow crown that rounds the mortal temples of a king

Keeps death his court; and there the antic sits...

... Comes at the last and with a little pin,

Bores through his castle wall and farewell king!

Competing interests None declared.

Provenance and peer review Commissioned; internally peer reviewed.

\section{REFERENCES}

1 http://www.cmhrc.co.uk/site/literature/royalcommissionreports/

2 Fletcher CM. Pneumoconiosis of coal-miners. Br Med J 1948;i:1015-22 and 1065-74.

3 Collis EL, Gilchrist JC. Effects of dust upon coal trimmers. J Indust Hyg 1928; 10:101-10

4 Hart P d'A, Aslett EA. Chronic pulmonary disease in South Wales coalminers 1. Medical studies. MRC Special Report Series 243, London, 1942.

5 Gough J. Pneumoconiosis of coal trimmers. J Path Bact 1940;51:277-85.

6 Cummins SL. The pneumonoconioses in South Wales. J Hyg (Lond) 1936;36:547-558.19.
7 Hamilton RJ, Walton WH. The selective sampling of respirable dust. In: Davies CN, ed. Inhaled particles and vapours. Oxford: Pergamon, 1961;465-75.

8 Jacobsen $M$, Rae $S$, Walton WH, et al. New dust standards for British coal mines. Nature 1970;227:445-7.

9 Rogan JM, Attfield M, Jacobsen M, et al. Role of dust in the working environment in development of chronic bronchitis in British coal miners. Br J Indust Med 1973;30:217-26.

10 Love RG, Miller BG. Longitudinal study of lung function in coal miners. Thorax 1983;37:193-7.

11 Lloyd MH, Gauld SJ, Soutar CA. Respiratory ill health among coal miners and telecommunication workers in South Wales. Br J Indust Med 1986;43:177-81.

12 Marine WM, Gurr D, Jacobsen M. Clinically important respiratory effects of dust exposure and smoking in British coal miners. Am Rev Respir Dis 1988;137:106-12.

13 Ruckley VA, Gauld SJ, Chapman JS, et al. Emphysema and dust exposure in a group of coal workers. Am Rev Respir Dis 1984;129:528-32.

14 Brown GM, Donaldson K. Inflammatory responses in lungs of rats inhaling coalmine dust: enhanced proteolysis of fibronectin by bronchoalveolar leukocytes. $\mathrm{Br} J$ Indust Med 1989;46:866-72.

15 Seaton A. Coalmining, emphysema, and compensation. Brit J Indust Med 1990;47:433-5

16 Evelyn J. Fumifugium, or the inconvenience of the Aer and Smoake of London Dissipated. 1661.

17 Seaton A, MacNee W, Donaldson K, et al. Particulate air pollution and acute health effects. Lancet 1995:345;176-8.

18 Royal Society and Royal Academy of Engineering. Nanoscience and nanotechnology; opportunities and uncertainties. London, The Royal Society, 2004.

19 Seaton A, Donaldson K. Nanoscience, nanotoxicology and the need to think small. Lancet 2005;364:923-4.

20 Poland CA, Duffin R, Kinloch I; , et al Long carbon nanotubes display asbestos-like pathogenic behaviour in a model of mesothelial exposure. Nature Nanotech 2008:3:423-8.

21 Seaton A. Galen, Gaia, and global climate change; Harvey and the history of air. J $R$ Coll Phys Edin 2007;37:357-61. 